\title{
LOCAL DEVELOPMENT IN THE POST-MINING COUNTRYSIDE? IMPACTS OF AN AGRICULTURAL AD PLANT ON RURAL COMMUNITY
}

\author{
Stanislav MARTINÁT ${ }^{1}$, Kamila TUREČKOV $\ddot{A}^{1}$
}

DOI: $10.21163 / G T \_2016.111 .07$

\begin{abstract}
:
The paper focuses in its first part on theoretical aspects and preconditions of the acceptance of the facilities for generating renewable energy with an emphasis on rural areas. Benefits and barriers of the relation between the rural development and renewable energies in conditions of the Czech Republic are discussed. By means of two questionnaire surveys $(2013,2015)$ the acceptance of the local anaerobic digestion (AD) plant by its local population was researched in the second part of the paper. It was found out that the level of the acceptance of projects for generation of renewable energy by local population varies in time, and a strong attention has to be devoted not only to planning and construction of the $\mathrm{AD}$ plant, but also to the operation of this facility so that undesirable impacts on quality of life of local population are minimized.
\end{abstract}

Key-words: Renewable sources of energy, AD plants, Acceptance, Rural regions, Czech Republic.

\section{INTRODUCTION}

Rural development is a rather indefinite collocation whose content is strongly influenced by subjective opinions of individual groups of population or individual inhabitants of rural spaces (Navrátil, Pícha \& Hřebcová, 2010) or (Navrátil et al, 2013). As there are large numbers of types of rural space (see e.g. Perlín, Kučerová \& Kučera, 2010), there is also a wide spectrum of individual preferences towards individual phenomena, processes or development projects that are implemented in rural areas. If we focus more on local development projects, we often come to the conclusion that there should be a clear fundamental agreement that there is a set of projects which are considered beneficial to the public. Though its definition is rather vague, (see e.g. Sieber, 2005) we can assume that such types of projects also include the ones that support the development of use of renewable sources of energies as solar, wind and geothermal energy or energy generated from biomass. It is undisputable that renewable energy projects whose location is of crucial importance for their profitability, usefulness and success rise many controversies among local communities.

Such controversies may be caused by both exogenous and endogenous factors. While the exogenous factors (such as unsuitably framed national or regional subvention policy, unclear legislation for the support of renewable sources or the choice of inappropriate technology) could be perceived as hardly susceptive factors from the point of view of local population, the endogenous factors (such as the acceptance/refusal of the project, its location, underrating the maintenance of technology or misleading abidance of technological procedures) can be influenced via particular steps applied on the local level

\footnotetext{
${ }^{1}$ Silesian University in Opava, School of Business Administration in Karviná, 73340 Karviná, Czech Republic,martinat@opf.slu.cz, tureckova@opf.slu.cz.
} 
(Devine-Wright, 2005). The acceptance of the given project on the local level by its local population can be considered as the crucial endogenous factor of a fundamental importance (Szymańska \& Chodkowska-Misczuk, 2011).

It is a generally known fact that fossil sources of energy (oil, coal, natural gas) are depletable sources, whose using is accompanied by negative externalities such as environmental pollution (Otáhal, 2009), worsened quality of life of local population (Pasten \& Santamarina, 2012) or reduced tourism potential (Frantál \& Kunc, 2011). Another less favourable trend concerning exploitation of depletable resources is the climate change and global warming (Turton \& Barreto, 2006). As it is obvious from the above mentioned arguments, the support for renewable sources of energies should be widespread. Yet, the reality is a bit complicated. The energy generated from renewable sources is financially demanding under the condition of the EU countries (in comparison to classical sources) and its support from public budgets raises controversies (Jacobsson et al, 2006). Furthermore the location of certain types of facilities for generation of renewable energy creates unexpected difficulties, however it appears that with the respect to their spatially limited extent (for example biomass incinerators or anaerobic digestion - AD plants) in comparison to the traditional sources, (mines, heating or nuclear power plants, oilfields) they are unrivalled. Likewise, their relatively simple dismantling (PV's) in contrast to the localities where traditional raw material is processed and which are left vacant in the landscape for decades could be perceived as an advantage. Yet, the other "weak" factors have to be taken into account (Van der Horst, 2006; Van der Horst, 2007; Van der Horst, 2009). With the advancing deindustrialisation of the society, which can be generally described as a shift of labour force from the industry to the services (Corden \& Neary, 1982), the perception of places has dramatically changed, no matter whether it relates to the local population or tourists. The projects evoking a couple of decades ago enthusiasm in wide public for their technical perfection (constructions of dams, factories, nuclear power plants etc.) are today seen from a very different angle.

The disruption of the landscape character (by PV's), the coverage of agricultural land (by PV's), growing of agricultural plants for energy purposes (incineration plants for biomass) or the location of such facilities within the built-up area of the communities (anaerobic digestion plants - AD plants) - these are the phenomena that are closely linked to renewable sources of energies despite of their indisputable benefits, and they raise plenty of controversies in public. This is the reason why the local public acceptance of renewable sources of energies should be taken into consideration and researched. Nowadays, we are provided with a plenty of literature dealing with various aspects of the acceptance of renewable energies. The factors that influence the spatial distribution of wind power plants in the Czech Republic are surveyed by e.g. Cetkovský and Nováková (2009), Frantál and Kučera (2009), Frantál and Kunc (2010), who studied a wider framework of spatial relationships, environmental and socio-economical connections. The factors of acceptance of wind power plants (in Denmark and India) and PV's (in Germany and the United States) were examined by Sovacool and Ratan (2012), examples of acceptance of typologically different German projects for generation of renewable sources were investigated by Musall and Kuik (2011). From the point of view of the conceptual contribution to the topic, the study by Walker and Devine-Wright (2008), who discussed benefits of such projects for the local population on the community level, mustn't be ignored. The above mentioned controversies are further discussed in the studies by Jørgensen, Andersen and Cascaval (2012) or Roberts et al (2013). 
Another widely discussed concept that is closely linked to renewable energies is the so called NIMBY syndrome (Wolsink, 2000). This is an attitude of people who support renewable energies on global, national or regional level, yet not the local level. If such projects are located within the proximity of people's residential space, they tend to refuse it (NIMBY - Not-In-My-Backyard). This concept was surveyed in the context of the Czech Republic on the example of wind power plants by Frantál (2015) and Frantál and Kunc (2010, 2011). The links between the recent agricultural changes and the increase of importance of energy productive farming (agricultural anaerobic digestion plants) were studied on the example of the Czech Republic by Martinát et al (2013a, 2013c), or on the example of comparison between the approaches applied in the Czech Republic and Slovakia by Martinát et al (2013b). The recent trends in farming of the Czech Republic were studied by e.g. Věžník and Konečný (2011), Konečný (2014), Doležalová et al (2014), Ženka et al (2015). Position of individual sectors of economy in wider Central European context is reflected in studies by Tvrdon, Tuleja and Verner (2014) or Nevima and Majerová (2015).

The aim of the study is to evaluate the importance of the agricultural AD plant in Stonava (the Czech Republic) regarding rural development, and to ascertain how the perception and acceptance of the local agricultural AD plant has changed with local population during its planning and subsequent operation.

\section{METHODOLOGY AND DATA}

The presented research might be divided into two following phases. The first phase was devoted to the analyses of available documents, documentations and general information concerning the agricultural AD plant in Stonava (information originating in the local and regional media, information from the web page of the plant and municipality etc.). The aim of this phase was to gather all relevant information linked to planning, construction and operation of this $\mathrm{AD}$ plant. The second phase was focused on the research of the perception or acceptance of the local AD plant by its local population (older than 18 years) by means of questionnaire surveys. The survey has been conducted in two waves to cover the attitudes and opinions of local population of Stonava municipality in wider time period. The first wave of gathering of questionnaires in the streets of the municipality was realized during March 2013, the second wave took place two years later (during April 2015). The structure of the questionnaire was identical in both waves and the individual questions for the questionnaire ven prepared on the basis of the literature retrieval and previous similar researches (Frantál \& Prousek, 2016). To verify the understand-ability of the questions, a pre-survey has been organized during February 2013 on a testing sample of ten respondents. All questions included in the questionnaire were closed, yet enabling the respondents to express their opinions. The questionnaires were then gathered by means of semi-structured interviews. The results of the survey have been processed by means of standard statistical methods, which are explained in the following part of this paper.

During the first wave of the survey 120 respondents were asked in the streets of Stonava to complete the questionnaire. Merely 108 out of all the respondents responded to all parts of the questionnaire ( 8 persons proved no knowledge about the existence of the AD plant in Stonava). During the second wave (two years later) a similar method for gathering questionnaires was used, and 260 completed questionnaires were gathered. This time, around just 20 respondents refused to cooperate on the survey. It can be observed that in 
both waves of the questionnaire survey the return rate of the questionnaires was around 90 $\%$, owing to the direct addressing of the respondents in the streets of their municipality.

Table 1. The structure of respondents of two surveys in Stonava (2013, 2015).

\begin{tabular}{|l|c|c|}
\hline & $\mathbf{2 0 1 3}$ & $\mathbf{2 0 1 5}$ \\
\hline Number of respondents & 108 & 260 \\
\hline Gender - male & $43.7 \%$ & $53.5 \%$ \\
\hline Gender - female & $56.3 \%$ & $46.5 \%$ \\
\hline Age $-18-25$ years & $9.2 \%$ & $26.5 \%$ \\
\hline Age $-26-35$ years & $4.8 \%$ & $25.8 \%$ \\
\hline Age $-36-45$ years & $40.5 \%$ & $18.8 \%$ \\
\hline Age $-46-55$ years & $21.5 \%$ & $20.4 \%$ \\
\hline Age -56 and more years & $24.0 \%$ & $8.5 \%$ \\
\hline Education - primary & $8.1 \%$ & $2.7 \%$ \\
\hline Education - secondary without final exam & $28.6 \%$ & $21.6 \%$ \\
\hline Education - secondary wih final exam & $45.2 \%$ & $46.7 \%$ \\
\hline Education - tertiary & $18.1 \%$ & $29.0 \%$ \\
\hline
\end{tabular}

Source: own survey

The questionnaire was structured into twelve closed questions and it took approximately ten minutes to complete one form. It was relatively difficult to keep the balance of gender, age and qualification structure of the respondents due to the limited population of the municipality. In the first wave, a relatively lower number of respondents was gathered within the age category $26-35$ years (merely $4.8 \%$ of questionnaires), on the other hand, the respondents in the age category $46-55$ years ( $40.5 \%$ of questionnaires) were much more co-operative. In the second wave of gathering the questionnaires, a relatively lower number of questionnaires was collected in the age category 56 and more years $(8.5$ $\%$ ). Despite the relatively unbalanced age structure of both samples, we believe that they are representative and the data of this survey is sufficiently justified and relevant for the performed analyses (see Table 1 for more detailed structure of the respondents of both surveys).

\section{CASE STUDY OF THE AD PLANT IN STONAVA}

The agricultural AD plant in Stonava, whose operation, impacts and acceptance by local population is studied in this paper, is located in the southern part of the area of Stonava municipality in the Moravian Silesian Region in the eastern part of the Czech Republic. The AD plant is located outside the settled part of the municipality, with 1898 people (in 2015) living on the area of $13.86 \mathrm{~km}^{2}$. Stonava is located in the eastern part of Ostrava agglomeration in the proximity of Karviná $(8$ kilometres to the south-west of Karviná). The area of Stonava has been significantly affected by terrain expressions of mining activities (the occurrence of terrain depressions, lagoons and heaps), which have been taking place in here for more than 150 years. The influence of mining is also significant in the social structure of the studied municipality where a plenty of local people work in the nearby mines Darkov and ČSM (see Fig. 1 for an illustration of the geographical context). 


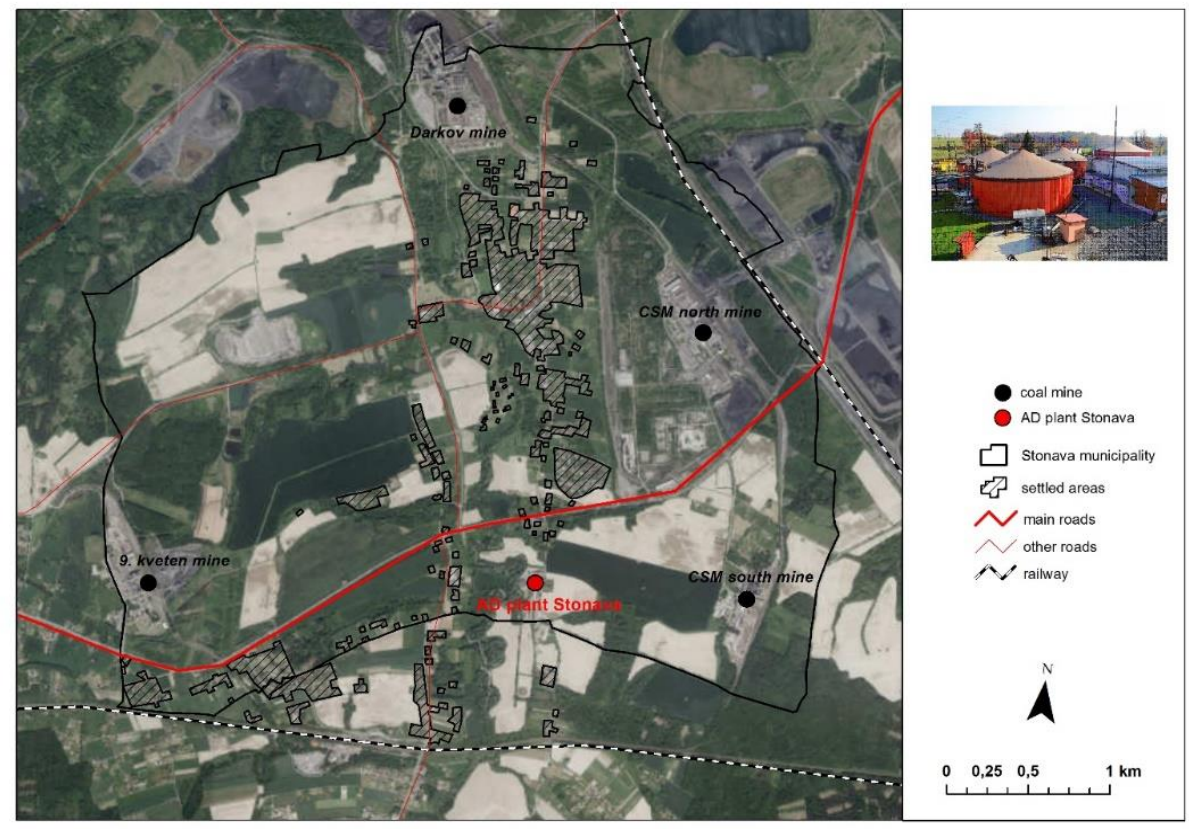

Fig. 1. Geographical context of the location of the agricultural AD plant in Stonava (Czech Republic) (Source: authors processing).

The agricultural AD plant in Stonava started to operate in 2009 (with an installed capacity of $537 \mathrm{~kW}$ ). Since 2011, the installed capacity of the AD plant has been more than doubled (to the installed capacity of $1381 \mathrm{~kW}$ ). The construction of the plant was supported by the government of the Czech Republic as a part of the Rural Development programme (1.8 million Euro), and then small public funding for the development of the documentation was provided by the administration of the Moravian-Silesian Region (see Table 2 for timeline of the project). The AD plant is owned by a local farmer who gave job to circa 60 local people.

As for the type of the AD plant, it is an agricultural plant, which means that the input material, by which the $\mathrm{AD}$ plant is fed, originates from agricultural activities of the local farm. An ideal source of material for an AD plant would be agricultural waste but in this case, the majority of inputs are covered by purpose grown maize, which is cultivated on local fields by the local farm. The Stonava farm operates on the area of 650 hectares of agricultural land, where almost one third of this area is covered by maize as the primary energy input for the local AD plant. Annually, the farm produces around 19 thousands of tons of maize to be processed in the $\mathrm{AD}$ plant. Due to the expansion of the installed capacity of the local AD plant in 2011, areas for growing maize are gradually increasing. Another source of material for the AD plant is pig manure from their own piggery where 2 thousands pigs are bred and this waste would otherwise stay unused without processing in the AD plant. Certain temporal changes of structure of input material for the local AD plant can be seen in Table 3. We can notice that while in the first period (2009-2010) when the $\mathrm{AD}$ plant was smaller, the majority of input material was represented by agricultural waste (pig manure), after increasing of the installed capacity of the AD plant in 2011 the majority 
of inputs is constituted by maize (more than $50 \%$ of inputs). Only $3 \%$ of its total material is covered by cut grass from the municipality. To ensure everyday fluent supplies of input material, it is necessary to transport 35-40 tons of biomass material daily. The mentioned structure of input material can be considered as unchangeable (to a certain level), as significant changes of the structure of input material might cause technological problems as well as production of typical odour.

Table 2. The timeline and milestones of the construction of the AD plant in Stonava.

\begin{tabular}{|l|l|}
\hline year & milestones \\
\hline $\mathbf{2 0 0 6}$ & $\begin{array}{l}\text { - first considerations of the construction of AD plant; - considerations regarding the type and } \\
\text { size of technology }\end{array}$ \\
\hline $\mathbf{2 0 0 7}$ & $\begin{array}{l}\text { - subvention for development of documentation of AD plant provided by regional authority; - } \\
\text { decision of investors on construction of AD plant (installed capacity } 537 \mathrm{~kW} \text { ); - subvention } \\
\text { for construction of AD plant provided by the Rural Development Programme (Ministry of } \\
\text { Agricultural of the Czech Republic); - zoning and building permits were issued }\end{array}$ \\
\hline $\mathbf{2 0 0 8}$ & - construction of AD plant starts \\
\hline $\mathbf{2 0 0 9}$ & - start of operation of AD plant with installed capacity $537 \mathrm{~kW}$ \\
\hline $\mathbf{2 0 1 0}$ & $\begin{array}{l}\text { - subvention for extension of existing AD plant from the Rural Development Programme; - } \\
\text { construction of extension of existing AD plant (installed capacity } 1381 \mathrm{~kW} \text { ) }\end{array}$ \\
\hline $\mathbf{2 0 1 1}$ & - start of operation of AD plant with installed capacity $1381 \mathrm{~kW}$ \\
\hline
\end{tabular}

Source: own survey

The outputs of the studies of the agricultural AD plant are shown in Table 4. Besides energy outputs in the form of electricity $(8.2 \mathrm{MW} / \mathrm{year})$ and heat $(8.5 \mathrm{MW} / \mathrm{year})$, digestate is produced (around 22 thousands of $\mathrm{m}^{3}$ annually), which is the rest after the process of the anaerobic fermentation which takes place in the AD plant. The digestate as a fertiliser of good quality deconcentrated and then distributed to local fields. The AD plant consumes around $70 \mathrm{kWh}$ of its own energy production, the rest of electricity is supplied by the distribution of the national energy company. As for heat energy, around $40 \%$ of heat is used for heating the halls and offices, a small amount of energy is delivered to a several family houses in the proximity of the $\mathrm{AD}$ plant as a compensation for the worsened quality of air in the area. Around one half of the heat energy produced stays unused.

Table 3. The changes of the structure of input material for the agricultural AD plant in Stonava (2009-2010, 2010 up to present).

\begin{tabular}{|l|c|c|c|c|}
\hline \multirow{2}{*}{} & \multicolumn{2}{|c|}{$\begin{array}{c}\text { installed capacity 500 kW } \\
\text { (2009-2010) }\end{array}$} & \multicolumn{2}{c|}{$\begin{array}{c}\text { installed capacity 500 kW } \\
\text { (since 2010) }\end{array}$} \\
\cline { 2 - 5 } & tons / year & \% & tons / year & \% \\
\hline pig manure & 7030 & 42.1 & 7030 & 25.8 \\
\hline maize & 6160 & 36.9 & 13240 & 48.6 \\
\hline grass silage & 500 & 3.0 & 1000 & 3.7 \\
\hline sugar beet chips & 3000 & 18.0 & 6000 & 22.0 \\
\hline total & 16690 & 100.0 .0 & 27270 & 100 \\
\hline
\end{tabular}

Source: Documentation for EIA process (Thiemel, 2007) 
Table 4. The changes of the structure of outputs / products of the agricultural AD plant in Stonava (2009-2010, 2010 up to present).

\begin{tabular}{|l|c|c|c|c|}
\hline \multirow{2}{*}{} & \multicolumn{2}{|c|}{$\begin{array}{c}\text { installed capacity 500 } \mathbf{k W} \\
\mathbf{( 2 0 0 9 - 2 0 1 0 )}\end{array}$} & \multicolumn{2}{c|}{$\begin{array}{c}\text { installed capacity 500 kW } \\
\text { (since 2010) }\end{array}$} \\
\cline { 2 - 5 } & $\mathbf{k W h} /$ year & $\mathbf{m}^{\mathbf{3}} /$ year & $\mathbf{k W h} /$ year & $\mathbf{m}^{3} /$ year \\
\hline electricity & 4100000 & - & 8200000 & - \\
\hline heat & 4280400 & - & 8560800 & - \\
\hline digestate & - & 14000 & - & 18000 \\
\hline
\end{tabular}

Source: Documentation for EIA process (Thiemel, 2007)

\section{ACCEPTANCE OF AD PLANT IN STONAVA}

The initial question of this survey focused on the attitudes of the local population of Stonava to the project of the AD plant during its planning (before the construction of the plant). We can say that four fifths of the respondents agreed with the construction of the $\mathrm{AD}$ plant during its planning, while just one tenth of the respondents were strongly against the project, and the same share of the people indicated that they had no information at all concerning this plan. Such results were ascertained in the survey in 2013, while two years later the share of the supporters slightly decreased and the share of opponents significantly increased (up to t $24 \%$ - see Table 5). This might be connected with the controversial experience of the local population with their local AD plant gained during its operational phase. Such hypothesis seems to be supported by the analysis of the second question of the survey, which inquired about the evaluation of changes in the municipality arising due to the operation of the local AD plant. We can notice that a negative perception of the impacts of the AD plant on the municipality was observed just in $5 \%$ of the answers of the respondents in 2013, while two years later the share doubled (10\%). Positive changes are perceived by one third of the respondents in both evaluated years (Table 6). Among positive consequences of the operation of the AD plant the following were usually stated - a reduction of the strong smell, which originated in the local piggery before the construction of the AD plant and now is significantly reduced. It has been also mentioned that the operator of the local $\mathrm{AD}$ plant is the most important employer in the municipality, which has an unemployment rate of above average (around $12 \%$ in 2015, while in the Czech Republic it is $6 \%$ ). Another aspect that might have positively influenced the local population and their perception of the local $\mathrm{AD}$ plant is widening of agricultural land in the municipality, which is caused by the operation of the plant and growing of maize as the main energy input for the plant. It can be supposed that the utilized agricultural land is perceived more positively by its local population than abandoned land, which had prevailed in the areas before the construction of the $\mathrm{AD}$ plant. Another reason for rather positive perception of the $\mathrm{AD}$ plant was the fact that the plant contributes to of the income of the local farmers.

If we discuss the negative perception of the $\mathrm{AD}$ plant, the share of its opponents has been significantly increasing in the course of time ( $5 \%$ of respondents in 2013 compared to $10 \%$ in 2015). In 2013 the opponents were primarily found among the people who live in the proximity of the AD plant, while in 2015 the area where the group of opponents live widened to a great extent. Such development might have been caused by problems with technology of the AD plant, which are rather rare and worsens the quality of life of the local population. As a certain form of a compensation measure the houses in the proximity of the $\mathrm{AD}$ plant are connected to the plant itself so that they can use the heat free of charge. 
Surprisingly, negative and sceptical attitudes of the local population towards the local AD plant were quickly reduced after the beginning of the operation of the AD plant (2009), yet it seems that opposition against the plant has been increasing during the course of time as a result of probably unfulfilled (and maybe unrealistic) expectations as for the benefits from the operation of the plant for the local development.

Table 5. Agreement with construction of agricultural AD plant in Stonava (2009) as perceived by respondents in 2013 and 2015.

\begin{tabular}{|l|c|c|}
\hline & $\mathbf{2 0 1 3}$ & $\mathbf{2 0 1 5}$ \\
\hline agreement with construction of AD plant & $81 \%$ & $76.6 \%$ \\
\hline resistance towards construction of AD plant & $10.1 \%$ & $24.2 \%$ \\
\hline not informed about construction of AD plant & $8.9 \%$ & $0.0 \%$ \\
\hline
\end{tabular}

Source: own survey $\left(n_{1}=108, n_{2}=260\right)$

Table 6. Evaluation of operation of agricultural AD plant in Stonava (2009) as perceived by respondents in 2013 and 2015.

\begin{tabular}{|l|c|c|}
\hline & $\mathbf{2 0 1 3}$ & $\mathbf{2 0 1 5}$ \\
\hline positive changes are obvious & $34.1 \%$ & $34.6 \%$ \\
\hline no changes & $60.9 \%$ & $55.4 \%$ \\
\hline negative changes are obvious & $5.0 \%$ & $10.0 \%$ \\
\hline
\end{tabular}

Source: own survey $\left(n_{1}=108, n_{2}=260\right)$

The above mentioned hypothesis can be confirmed by responses to a question which focused on the evaluation of the importance of the local AD plant for the local rural development. While two thirds of the respondents' responses were positive in 2013, in 2015 it was just $38.5 \%$ (see Table 7). Negative responses to this question increased more than three times between two surveys (to $22.9 \%$ in 2015).

Table 7. Evaluation of importance of agricultural AD plant in Stonava for rural development as perceived by respondents in 2013 and 2015.

\begin{tabular}{|l|c|c|}
\hline & $\mathbf{2 0 1 3}$ & $\mathbf{2 0 1 5}$ \\
\hline positive contribution for rural develoment & $66.9 \%$ & $38.5 \%$ \\
\hline no effect for rural develoment & $26.1 \%$ & $28.6 \%$ \\
\hline negative contribution for rural development & $7.0 \%$ & $22.9 \%$ \\
\hline
\end{tabular}

Source: own survey $\left(n_{1}=108, n_{2}=260\right)$

Other questions were focused on learning more about the operation of the local AD plant and its impact on the municipality. When asking about the impacts of the AD plant on the local environment, rather negative attitudes were ascertained. More than one third of the respondents believe that the local environment is influenced to a great extent by the operation of the local AD plant. This might be caused by rare technological problems in the AD plant as well as by an increase of traffic in the municipality resulting from the regular supplies to the AD plant. It has to be stated that the AD plant in Stonava is located outside the settled part of the municipality; however the use of the local roads for transporting the input material to the AD plant has undoubtedly increased. A higher frequency of using the local agricultural land for growing maize for the $\mathrm{AD}$ plant might be also perceived negatively due to the increase of dust from fields, higher transport intensity in the municipality, a higher risk of erosion or usage of digestate as a fertilizer for the local fields. 
Even though such situations appear rarely, they might cause controversies regarding the attitudes of the local population towards the AD plant.

The next set of questions was focused on potential benefits and impacts of the AD plant operation perceived by the respondents. A set of statements connected to the potential positive benefits and potential negative impacts were selected based on the literature retrieval, and individual options were evaluated on a scale of responses ranging from definitely disagree to definitely agree. Each of five possible responses was evaluated by points ranging from an option "the least benefit for the community" (1 point), "a neutral contribution for the community" ( 3 points) and "the highest benefit for the community" (5 points). Individual answers were calculated to obtain a total score which was further divided by a number of respondents (108 in 2013, 260 in 2015) to acquire comparable results. As it is obvious from the Table 8, in 2013 the most positive statement noticed was "production of clean and renewable energy" followed by "contribution to the protection of the environment). If we study the results from 2015, we can observe that the first place is similar ("production of clean and renewable energy"), the second highest is "new jobs opportunities", while "contribution to protection of environment" maintained the similar level. This result might be interpreted as a result of a lack of job opportunities in its wider region, which was heavily affected by a decrease in jobs in heavy industry and mining (Martinát et al, 2015).

If we focus now on negative impacts of the AD plant operation in Stonava (Table 9), we can see that all responds were evaluated more negatively in 2015 than in 2013. The most problematic issue identified in 2013 was ,the worsening of the quality of life of the local population“ (noise, smell), while in 2015 is was „doesn't significantly contribute to profit of municipality“. It implies that the respondents believed that the benefits of the local AD plant operation could be much higher than they really are at present.

Table 8. Comparison of positive contributions of operation of AD plant in Stonava.

\begin{tabular}{|l|c|c|c|}
\hline & $\mathbf{2 0 1 3}$ & $\mathbf{2 0 1 5}$ & tendency \\
\hline production of clean and renewable energy & 3.79 & 3.99 & \\
\hline contribution to protection of environment & 3.71 & 3.65 & \\
\hline utilisation of material that stays unused & 3.57 & 3.62 & \\
\hline new jobs opportunities & 3.48 & 3.73 & \\
\hline contribution to overall development of municipality & 3.28 & 3.03 & \\
\hline generation of economic profit for municipality & 3.14 & 3.25 & \\
\hline contribution to promotion of municipality & 3.08 & 2.82 & \\
\hline
\end{tabular}

Source: own survey $\left(n_{1}=108, n_{2}=260\right)$

Table 9. Comparison of negative impacts of operation of AD plant in Stonava as perceived.

\begin{tabular}{|l|c|c|c|}
\hline & $\mathbf{2 0 1 3}$ & $\mathbf{2 0 1 5}$ & tendency \\
\hline worsened quality of life of local population & 2.41 & 2.82 & \\
\hline is economically unprofitable & 2.21 & 2.73 & \\
\hline doesn't significantly contribute to the profit of municipality & 2.21 & 2.95 & \\
\hline decrease prices of real estates in municipality & 2.15 & 2.71 & \\
\hline causes conflicts and disintegration of municipality & 2.01 & 2.37 & \\
\hline threatens environment & 1.87 & 2.18 & \\
\hline discourages tourists to come to municipality & 1.58 & 2.59 & \\
\hline
\end{tabular}

Source: own survey $\left(n_{1}=108, n_{2}=260\right)$ 
We can say that the evaluation of the benefits and negative impacts of the AD plant operation in Stonava brought quite surprising results. The temporal change of evaluated attributes put more light on our notion that once the facility for generation of renewable energy is constructed and in operation, its acceptance by the local community is relatively stable. It is a fact that the population of the surveyed Stonava municipality adapted to life in the proximity of the local AD plant; still the opinions of the local population regarding the benefits of the AD plant operation can quickly change in the course of time. At the very beginning of the project the increase in the employment in the municipality was satisfactory enough for the local population, while several years later the local population feel that the opportunities for the local development due to the AD plant are relatively underused. The local population believe that if large sums of public money were invested in building the facility, and the AD plant is supported by the state by means of guaranteed prices for its generated electricity, it should be also reflected in people's payments for the electricity (to compensate the location of the AD plant in the municipality) and the heat from the $\mathrm{AD}$ plant should be used for heating the public buildings etc. The high level of support for the local AD plant immediately after its construction might be also interpreted as a form of support for the local decaying farming and the locally important employer. On the other hand, only two persons work at the local AD plant and it is highly unlikely to expect any larger increase in this type of job opportunities.

An increase of scepticism of the local population towards the local AD plant in the recent period of time might be also related to the specifities of the population living in the areas heavily affected by heavy industry and mining, where due to recent significant reductions of industrial activities worsened atmosphere prevails. On the other hand, the local long-term coexistence of industry and agriculture might be beneficial for a better acceptance of the AD plant by its local population still extensively engaged in industry, and also for the needs of the local farming being the producer of the input material for the AD plant. This fact might be a sufficient argument for the population to have understanding for the noise and occasional smell caused by the local agricultural activities.

Another fact, which significantly improves the chances for the acceptance of the local AD plant, is its ownership by the local citizen who is familiar with the problems of the local community to a great extent. The fact that the smell from the former piggery has been significantly reduced after the $\mathrm{AD}$ plant construction is also one of the supportive arguments for the increased acceptance of the AD plant after the beginning of its operation. What might be perceived as an interesting fact is that no comments or objections were detected towards growing maize for energy purposes on agricultural land. This fact illustrates the ethical issues when growing energy crops on land which should be primarily used for growing food, and the local people are not concerned about this matter at all. This indirect result of the study deserves a deeper research so that we can detect the causes of such ignorance.

\section{CONCLUSION}

The local acceptance of projects for generation of renewable energy might be perceived as a certain type of self-regulatory mechanism, which makes it possible that projects with economic, social or environmental controversies are eliminated. We assume, of course that population actively participate in the development of these projects, which is not always the fact. Especially in the areas significantly affected by heavy industry and mining, where specific educational structure of population is typical quite limited 
participation of the local population in public matters can be noticed. An important influence is also the fact that renewable energies do not have such a good reputation in the Czech Republic, where the recent huge increase in their utilisation has been accompanied by a plenty of scandals and misguiding governmental supportive policy.

As a consequence of the obligation of the Czech Republic towards the European Union, the share of energy produced from renewable sources shall be increased to $13.5 \%$ by 2020 . It can be assumed that the sector of AD plants will be further developed despite of more than 500 operating AD plants in early 2016. The question is how this boom can be regulated so that the invested public money is used wisely, and the negative impacts on life in rural communities are reduced to a minimal level. A consensus between indisputable benefits for the global environment and possibly negative impacts on the local level has to be found. The acceptance of these projects by their local population during the planning, construction and operation has to be understood as an indisputable assumption for the success of these projects. Agricultural AD plants in the Czech Republic are still perceived more as a means for increasing the income of the farmers in the days when the traditional agriculture is in decline rather than a tool for protecting the environment on both the local and global scale.

The agricultural AD plant in Stonava might be perceived as an example of a facility whose acceptance by its local population was high at the time of the beginning of the operation of the project, but later multiple problems emerged. To sum it up, it is necessary to understand the acceptance of renewable energy as a dynamic process that has to be governed at the local level, so that as many benefits as possible are utilized for the local development (use of energy and heat). In the specific context of surveyed community it would be also highly beneficial to use local heaps and landscape affected by post-mining effects for growing of energy crops for local AD plant instead of energy-utilisation of open agricultural land.

\section{ACKNOWLEDGEMENT}

This research was kindly supported by the students' grant project with title 'Influence of Selected Macroeconomic and Microeconomic Determinants on the Competitiveness of Regions and Firms in Countries of the Visegrad Group Plus" (project registration number is SGS/13/2015).

\section{R E F E R E N C E S}

Cetkovský, S. \& Nováková, E. (2009) Assesment of the impact of wind turbines on landscape character: implications for landscape planning. Moravian Geographical Reports, 17 (2), 28-34.

Corden, W. M. \& Neary, J. P. (1982) Booming sector and de-industrialisation in a small economy. Seminar Paper No. 195, University of Stockholm, 39.

Devine-Wright, P. (2005) Local aspects of UK renewable energy development: exploring public beliefs and policy implications. Local Environment, 10 (1), 57-69.

Doležalová, H., Pícha, K., Navrátil, J. \& Bezemková, A. (2014) Changes in the structure of the regional agricultural production (South Bohemian Region). Journal of Central European Agriculture, 15 (3), 335-353.

Frantál, B. \& Prousek, A. (2016) It's not right, but we do it. Exploring why and how Czech farmers become renewable energy producers. Biomass and Bioenergy, 87, 26-34. 
Frantál, B. (2015) Have local government and public expectations of wind energy project benefits been met? Implications for repowering schemes. Journal of Environmental Policy \& Planning, 17 (2), 217-236.

Frantál, B. \& Kučera, P. (2009) Impacts of the operation of wind turbines as perceived by residents in concerned areas. Moravian Geographical Reports, 17 (2), 35-45.

Frantál, B. \& Kunc, J. (2010) Factors of the uneven regional development of wind energy projects (a case of the Czech Republic). Geografický Časopis / Geographical Journal, 62 (3), 183-201.

Frantál, B. \& Kunc, J. (2011) Wind turbines in tourist landscape: Czech experience. Annals of Tourism Research, 38, (2), 499-519.

Jacobsson, S., Bergek, A., Finon, D., Laumer, V., Mitchell, C., Toke, D. \& Verbruggen, A. (2006) EU renewable energy support policy: Faith or facts? Energy Policy, 37 (6), 2143-2146.

Konečný, O. (2014) Geographical perspectives on agritourism in the Czech Republic. Moravian Geographical Reports, 22 (1), 15-23.

Jørgensen, M. S., Andersen, B. H. \& Cascaval, D. (2012) The controversies over bioenergy in Denmark:'bio'is not the same as' sustainable'. Environmental Engineering and Management Journal, 11 (11), 2101-2119.

Martinát, S., Kunc, J., Klusáček, P., Krejčí, T., Navrátil, J., Vnenková, J. \& Černík, J. (2015) Spatial relations and perception of brownfields in old industrial region: case study of Svinov (Ostrava, Czech Republic). Geographia Technica, 10 (2), 66-77.

Martinát, S., Mintálová, T., Dvořák, P., Navrátil, J., Klusáček, P. \& Kunc. J. (2013a) Does rural space benefit from location of anaerobic digestion plants? Perspective of communal administration. Geographia Cassoviensis, 7 (2), 44-49.

Martinát, S., Dvořák, P., Navrátil, J., Klusáček, P., Kulla, M., Mintálová, T. \&. Martinátová, I. (2013b) Importance of agricultural anaerobic digestion plants for agriculture and rural development: notes on researc hes carried out in the Czech Republic and Slovakia. Proceedings of the 6th International Scientific Conference Rural Development 2013, vol. 6, Book 2, 168-176.

Martinát, S., Dvořák, P., Frantál, B., Klusáček, P., Kunc, J., Kulla, M., Mintálová, T., Navrátil, J. \& Van der Horst, D. (2013c) Spatial consequences of biogas production and agricultural changes in the Czech Republic after EU accession: mutual symbiosis, coexistence or parasitism? Acta Universitatis Palackianae Olomucensis-Geographica, 44 (2), 75-92.

Musall, F. D. \& Kuik, O. (2011) Local acceptance of renewable energy - A case study from southeast Germany. Energy Policy, (39) 6, 3252-3260.

Navrátil, J., Pícha, K. \& Hřebcová, J. (2010): The importance of historical monuments for domestic tourists: The case of South- Western Bohemia (Czech Republic). Moravian Geographical Reports, 18 (1), 45-61.

Navrátil, J., Picha, K., Martinat, S., Knotek, J., Kucera, T., Balounova, Z., White Baravalle Gilliam, V. L., Svec, R. \& Rajchard, J. (2013) A model for the identification of areas favourable for the development of tourism: A case study of the Šumava Mts. and South Bohemia tourist regions. Moravian Geographical Reports, 21 (1), 25-40.

Nevima, J. \& Majerová, I. (2015) The application of two econometric models in the $\beta$-convergence approach in the case of Visegrad Four Regions. Transformations in Business and Economics, 14 (2 A), 549-562.

Otáhal, T. (2009) Problém zastoupení v institucionální ekonomii. Politická ekonomie, 57 (5), 677695.

Pasten, C. \& Santamarina, J. C. (2012) Energy and quality of life. Energy Policy, 49, 468-476.

Perlín, R., Kučerová, S. \& Kučera, Z. (2010) Typologie venkovského prostoru Česka. Geografie, 115 (2), 161-187.

Roberts, T., Upham, P., Boucher, P., Mclachlan, C., Mander, S., Gough, C. \& Ghanem, D. A. (2013) Conclusions and a research agenda for the social science of energy supply controversy. In Roberts, T. et al. (eds). Low-carbon energy controversies. Abingdon: Routledge, 259-270. 
Sieber, P (2005) Investiční rozhodování a veřejně prospěšné projekty. Acta Oeconomica Pragensia, 13 (4), 62-79.

Sovacool, B. K. \& Ratan, P. L. (2012) Conceptualizing the acceptance of wind and solar electricity. Renewable and Sustainable Energy Reviews, 16 (7), 5268-5279.

Szymańska, D. \& Chodkowska-Miszczuk, J. (2011) Endogenous resources utilization of rural areas in shaping sustainable development in Poland. Renewable and Sustainable Energy Reviews, 15 (3), 1497-1501.

Thiemel, J. (2007) Bioplynová stanice Stonava. Oznámeni podle zákona č. 100/2001 Sb., o posuzování vlivů na životni prostředí. Stonava: Informační systém Cenia, 48.

Turton, H. \& Barreto, L. (2006) Long-term security of energy suply and climate change. Energy Policy, 34 (15), 2232-2250.

Tvrdon, M., Tuleja, P. \& Verner, T. (2012) Economic performance and the labour market in the context of the economic crisis: experience from the Visegrad four Countries. E+M Ekonomie a Management, 15 (7), 16-32.

Van der Horst, D. (2006) Spatial cost-benefit thinking in multi-functional forestry; towards a framework for spatial targeting of policy interventions. Environmental Economics, 59, 171-180.

Van der Horst, D. (2007) NIMBY or not? Exploring the relevance of location and the politics of voiced opinions in renewable energy siting controversies. Energy policy, 35 (5), 2705-2714.

Van der Horst D. (2009) Spatial planning of wind turbines and the limits of 'objective' science. Moravian Geographical Reports, 17 (2), 46-51.

Věžník, A. \& Konečný, O. (2011) Agriculture of the Czech Republic after accession to the EU: regional differentiation. Moravian Geographical Reports, 19 (1), 50-60.

Walker, G. \& Devine-Wright, P. (2008) Community renewable energy: What shoud it mean? Energy Policy, 36, 497-500.

Wolsink, M. (2000) Wind power and the NIMBY-myth: institutional capacity and the limited significance of public support. Renewable energy, 21, 49-64.

Ženka, J., Žufan, P., Krtička, L. \& Slach, O. (2015) Labour productivity of agricultural business companies and cooperatives in the Czech Republic: A micro-regional level analysis. Moravian Geographical Reports, 23 (4), 14-25. 